$9-1-2011$

\title{
Growth Potential of Tourism Taxation in Maldives
}

\author{
Fazeel Najeeb \\ Governor of the Maldives Monetary Authority \\ Mehmet S. Tosun \\ University of Nevada-Reno
}

Follow this and additional works at: https://ecommons.luc.edu/meea

Part of the Economics Commons

\section{Recommended Citation}

Najeeb, Fazeel and Tosun, Mehmet S., "Growth Potential of Tourism Taxation in Maldives". Topics in Middle Eastern and North African Economies, electronic journal, 13, Middle East Economic Association and Loyola University Chicago, 2011, http://www.luc.edu/orgs/meea/

This Article is brought to you for free and open access by the Journals and Magazines at Loyola eCommons. It has been accepted for inclusion in Topics in Middle Eastern and North African Economies by an authorized administrator of Loyola eCommons. For more information, please contact ecommons@luc.edu. (c) 2011 the authors 


\section{Growth Potential of Tourism Taxation in Maldives}

In this paper, we examine the tourism sector in Maldives, focusing on tax revenue generation and long-run growth potential. We present a sectoral outlook for tourism and use time-series econometric techniques to estimate long-run tax base elasticities. We focus specifically on international tourist arrivals and international tourism receipts as two alternative tax bases in the tourism sector. We use data from the World Bank's World Development Indicators and the World Tourism Organization for the period 19952009. Our findings suggest a strong long-run growth potential for revenue generation from tourism in Maldives, where the revenue growth potential is stronger in the case of the international tourism receipts.

March 2011

Keywords: Maldives, tax base elasticity, tourism tax, small island economies

JEL Classification: H20, H30, L83

Fazeel Najeeb

Governor

Maldives Monetary Authority

Majeedhee Building

Boduthakurufaanu Magu

Male 20182, Republic of Maldives

+(960) 332-5058

governor@mma.gov.mv
Mehmet S. Tosun

Associate Professor

Department of Economics

Mail Stop 0030

College of Business Administration

University of Nevada, Reno

Reno, NV 89557 U.S.A.

$+(1)$ (775) 784-6678

tosun@unr.edu 


\section{Introduction}

Small island economies have been suffering from serious fiscal problems in recent times. Maldives had one of the worst fiscal outlooks among these economies. The Maldives is a sovereign nation of 1,192 islands ${ }^{1}$ located in the Indian Ocean to the south west of India. The population is $309,575^{2}$ who inhabit on 194 islands. ${ }^{3}$ The country's nominal GDP for 2009 is estimated at USD1,473mn. ${ }^{4}$ The World Bank classifies the Maldives as a lower middle-income country (LMC, i.e. a country that has a GNI per capita of USD976-3,855) according to the 2008 figures. ${ }^{5}$ The national currency is the Rufiyaa which is pegged to the US\$. The current fixed exchange rate of US\$1=Rf12.80 has been in place since the last devaluation from Rf 11.77 in the middle of 2001.

In this paper, we examine the tourism sector in Maldives, focusing on the longrun growth potential from this revenue source. Our goal is to determine the long-run growth potential in the country by estimating long-run tax base elasticities. We start with a sectoral outlook for tourism and then use time-series econometric techniques to get elasticity estimates that can be compared to other tax bases and elasticity estimates from other related studies. We focus specifically on international tourist arrivals and international tourism receipts as two alternative tax bases in the tourism sector. We use data from the World Bank’s World Development Indicators and the World Tourism

\footnotetext{
${ }^{1}$ Department of National Planning (2010), Statistical Yearbook 2009, available at http://planning.gov.mv/yearbook2009/, visited 27 March 2010.

${ }^{2}$ Department of National Planning (2010), Statistical Yearbook 2009, available at http://planning.gov.mv/yearbook2009/, visited 27 March 2010.

${ }^{3}$ Department of National Planning (2010), Statistical Yearbook 2009, available at http://planning.gov.mv/yearbook2009/, visited 27 March 2010.

${ }^{4}$ Maldives Monetary Authority, Monthly Statistics Vol. 11 No. 3, March 2010, available at http://www.mma.mv/Monthly\%20Statistics/mar10.pdf, visited 26 March 27, 2010.

${ }^{5}$ World Bank, World Development Report 2010, available at http://siteresources.worldbank.org/INTWDR2010/Resources/5287678-1226014527953/WDR10-FullText.pdf, p. 377, visited 26 March 27, 2010.
} 
Organization for the period 1995-2009. Our findings suggest a strong long-run growth potential for revenue generation from tourism in Maldives. We also find a stronger growth potential in the international tourism receipts compared to international tourist arrivals.

The paper is structured as follows. The next section provides an outlook for the tourism sector and describes tax and non-tax revenue instruments. This is followed by an empirical analysis of the long-run revenue growth potential. The last section summarizes results and provide our concluding remarks.

\section{Tourism Sector Outlook and Revenues}

There is a wide-ranging literature on the economic impact of tourism particularly for small island economies. Reece (2010) discusses in detail the multidimensional nature of the tourism impacts and defines the economic impact of tourism as "changes in regional employment, incomes, tax payments, and other measures of economic activity, along with social and environmental impacts that result from a region's tourism development.” Many other studies discuss and show evidence of the revenue impact of tourism in Maldives and other small island economies (Sathiendrakumar and Tisdell, 1989; McKee and Tisdell, 1990; Kakazu, 1994; Gooroochurn and Sinclair, 2005; Croes, 2006). ${ }^{6}$

Maldives is indeed a premium tourist destination and its economy is heavily dependent on tourism. Figure 1 shows that the contribution of tourism to GDP in 2008 was $27 \%$ (the second highest contributor to the GDP was transport/communication with $19 \%$ followed by $17 \%$ from government administration). Tourism also accounts for $16 \%$,

\footnotetext{
${ }^{6}$ See also Mckee and Tisdell (1990), Kakazu (1994) and Read (2004) for some of the challenges that could limit revenue capabilities in small island economies.
} 
the third highest, of the total employment. ${ }^{7}$ The highest number of people is employed in the wholesale and retail trade (19\%) followed by manufacturing (18\%).

Since the advent of tourism in Maldives in early $1972,{ }^{8}$ the country has increasingly relied on this industry. In 1984 the contribution of tourism to GDP was 29.4\%. ${ }^{9}$ Tourism contribution to GDP peaked in 1996 at 35\%. However, the corresponding figure for 2005 plummeted to $22.7 \%{ }^{10}$ (lowest ever) following the Asian tsunami on 26 December 2004. The figure is estimated to be $24.6 \%$ in 2009 . Total bed capacity increased from 3,915 in $1981^{11}$ to 23,464 in 2008.

As shown in Figure 2, tourist arrivals in 2004 peaked at 616,716 but slumped to 395,320 in 2005 following the tsunami in December 2004. It bounced back in 2006 with 601,923 and continued to increase to 683,012 in 2008 before falling to 655,852 in 2009 during the height of the financial crisis. The tourist arrival numbers are also shown in Table 1 with other tourism indicators. Average bed capacity utilization rate remained just under $75 \%$ over the last decade. After peaking at $83.9 \%$ in 2004 , utilization rate dropped to $64.5 \%$ in 2005 following the tsunami. While it recovered after the tsunami starting in 2006, the capacity utilization rate dropped again to $70.4 \%$ following the financial crisis. We see a similar trend in tourist bednights as well. It is also noteworthy that the average days of stay also fell noticeably over the last decade. It is quite clear from these indicators

\footnotetext{
${ }^{7}$ Department of National Planning (of Maldives), Economic Survey 2007, available at

${ }^{8}$ For historic developments in tourism in the Maldives see Ahmed Niyaz, Tourism in the Maldives: 25 years of sustainable development, Maldives 1998.

${ }_{9}^{9}$ Ministry of Planning and National Development (2005), 25 Years of Statistics, available at http://www.planning.gov.mv/publications/25yearsstats/default.htm, visited 27 March 2010.

${ }^{10}$ Department of National Planning (2010), Statistical Yearbook 2009, available at http://planning.gov.mv/yearbook2009/, visited 27 March 2010.

${ }^{11}$ Ministry of Planning and National Development (2005), 25 Years of Statistics, available at http://www.planning.gov.mv/publications/25yearsstats/25_yrs_stats/9_Tourism/9.4.htm, visited 27 March 2010.
} 
that tourism in Maldives suffered significantly from external events such as the tsunami and the world financial problems.

In the absence of a direct tax (such as an income tax) in the Maldives, there has been heavy reliance on indirect taxes and non-tax revenue for government finance. Import duty, tourism tax and tourism resort lease rent are the largest sources of revenue to the government.

The share of receipts from tourism to the total government revenue in 1994 was 28.6\%. The figure peaked at $34.2 \%$ in 2002 . The lowest ever share of tourism receipts to government revenue was in 2009 with an estimated 16.2\%. This large drop follows the slump in the economy following the global financial crisis.

Revenue to government from tourism comes mainly in the form of lease rent and tourism tax payments. In 2007 tourism tax collection amounted to Rf 547.3mn. This increased to Rf 588.7mn (17.4\% of the total tax revenue) and Rf $496.2 \mathrm{mn}$ (20.1\% of the total tax revenue) in 2008 and 2009 respectively. Despite an absolute drop in tourism revenue in 2009 due to a significant drop in tourist arrivals in 2009 amid the global financial crisis, tourism tax showed an increase as a percentage of the total tax revenue. This is due to a substantial reduction in import duty revenue which has by far the largest share of total tax collections (72.5\% in 2008 and 56.6\% in 2009). ${ }^{12}$

Of non-tax revenue, tourism resort lease rent is by far the biggest contributor. In 2007 resort lease rent contributed Rf 1668.7mn. The figures for 2008 and 2009 were Rf 1513.6mn and Rf 1051.2mn respectively.

\footnotetext{
${ }^{12}$ Import duty is also the largest tax contributor to government finance in absolute terms ( $\mathrm{Rf} 2086.5 \mathrm{mn}$ in 2007; Rf 2459.9mn in 2008); and Rf 1816.7mn in 2009).
} 
The government has a history of deficit budgets. Following the Boxing Day tsunami in December 2004, budget deficit shot up from Rf 157.9mn in 2004 to Rf 1044.7mn (just under $11 \%$ of the GDP) in 2005. Since then the deficit has deteriorated to Rf 4923.6mn (just over 26\% of the GDP) in 2009.

While the government has taken measures to curb its expenditure drastically, the country also remains at a very vulnerable position on the revenue side. Recognizing the need to address the fiscal problems immediately for long term stability the government is working on legislation to diversify the government's revenue base. Among the measures are a tourism goods and services tax (TGST) in the short term, an increase in the tourism tax in the short term, a business profits tax (BPT) in the short term, and a goods and services tax (GST) in the medium term.

\section{Empirical Analysis}

We use data from the World Bank's World Development Indicators databse. We use GDP data for Maldives as well as for few other relevant tourist sending regions, namely European Union, Organization for Economic Cooperation and Development (OECD), High income countries, and North America. Data on international tourism receipts and international tourist arrivals come from World Tourism Organization, Yearbook of Tourism Statistics. ${ }^{13}$ That data also appears in the World Bank’s World Development Indicators database, which was the source we used in our empirical

\footnotetext{
${ }^{13}$ As reported in the WDI database, "international inbound tourists (overnight visitors) are the number of tourists who travel to a country other than that in which they usually reside, and outside their usual environment, for a period not exceeding 12 months and whose main purpose in visiting is other than an activity remunerated from within the country visited. When data on number of tourists are not available, the number of visitors, which includes tourists, same-day visitors, cruise passengers, and crew members, is shown instead." "International tourism receipts are expenditures by international inbound visitors, including payments to national carriers for international transport. These receipts include any other prepayment made for goods or services received in the destination country. They also may include receipts from same-day visitors, except when these are important enough to justify separate classification. For some countries they do not include receipts for passenger transport items. Data are in current U.S. dollars.”
} 
analysis. All variables, except international tourist arrivals, are used in (or converted to) constant U.S. dollars with 2000 as the base year. Summary statistics for these variables are shown in Table 2. Natural logs of these variables are used in the regressions.

We use the following basic regression specification to estimate the long-run tax base elasticity: ${ }^{14}$

$$
T_{t}=\beta_{0}+\beta_{1} G D P_{t}+\varepsilon_{t}
$$

where $T_{t}$ is the natural $\log$ of tourism receipts (or tourist arrivals) at time t, $G D P_{t}$ is the natural $\log$ of the Gross Domestic Product at time t. The coefficient of $G D P_{\mathrm{t}}$ provides the tax base elasticity that shows the long-run response of the tax base to the change in overall economic activity.

Augmented Dickey-Fuller and Phillips-Perron unit root tests of the variables in Equation (1) reveal that while tourism receipts and tourist arrivals are stationary, the GDP variable is nonstationary. However, we find a cointegrating relationship among the variables in equation (1). We also use heteroskedasticity and autocorrelation consistent (HAC) standard errors and estimate our regression equation using the Newey-West (1987) standard errors.

We estimate the response of international tourist arrivals, which was the tax base prior to recent legislation, as well as international tourism receipts (the tax base of the new TGST) to changes in economic activity. Regression results are shown in Table 3. Numbers in the table are the coefficient estimates of $\beta_{1}$ in equation 1 which are also the long-run elasticity estimates. We start with the response of these tax bases to GDP of Maldives. We see that both long-run elasticity estimates are less than 1 with a higher

\footnotetext{
${ }^{14}$ This approach is similar to other long-run tax base elasticity estimations in the public finance literature. See Fox and Campbell, 1984; Dye and McGuire, 1991; Sobel and Holcombe, 1996; Bruce et al., 2006; Nichols and Tosun, 2008.
} 
estimate under the tourism receipts tax base. These may not be very accurate, however, since both tourist arrivals and tourism receipts respond more to income and economic activity in other tourist sending countries, which are also in relatively higher income regions. We see that the elasticity estimates are significantly higher when we look at the response to GDP of those regions and countries. While most elasticity estimates are greater than 2, the estimates are lowest in the case of North American countries and highest in the case of European Union countries. This certainly makes intuitive sense since European Union is the largest tourist sending country group for Maldives tourism. We also see in Table 3 that the long-run elasticity estimates are consistently higher for the international tourism receipts in all regressions

\section{Summary and Conclusion}

In this paper, we examined the response of the tourism sector in Maldives to changes in economic activity in Maldives and tourist sending high income regions. We focused specifically on international tourist arrivals and international tourism receipts as two alternative tax bases in the tourism sector. Our findings show that the long-run elasticity estimates for these two tax bases are quite high (greater than 1) particularly for the responses to the GDP of high income tourist sending regions. Such high responsiveness is an indication of a strong long-run growth potential for revenue generation from tourism in Maldives. We also find that this growth potential is particularly strong for the international tourism receipts compared to international tourist arrivals.

We would like to conclude by noting that we focused solely on the long-run tax base elasticity in this paper, refraining from any volatility issues. Volatility (or 
variability) in tourism taxation requires estimation of short-run tax base elasticity. While revenue volatility has been addressed recently for some island economies (e.g. Purfield, 2005), that has not been done for Maldives specifically, which is a good area for future research. 


\section{References}

Bruce, Donald, William F. Fox and M.H. Tuttle. 2006. "Tax Base Elasticities: A MultiState Analysis of Long-Run and Short-Run Dynamics.” Southern Economic Journal 73 No. 2 (October): 315-41.

Croes, Robertico R. 2006. “A Paradigm Shift to a New Strategy for Small Island Economies: Embracing Demand Side Economics for Value Enhancement and Long Term Economic Stability,” Tourism Management 27: 453-465.

Dye, Richard F., and Therese J. McGuire. 1991. "Growth and Variability of State Individual Income and General Sales Taxes.” National Tax Journal 44 No. 1 (March): 55-66.

Fox, William F., and Charles Campbell. 1984. "Stability of the State Sales Tax Income Elasticity.” National Tax Journal 37 No. 2 (June): 201-12.

Gooroochurn, Nishaal and M. Thea Sinclair. 2005. "Economics of Tourism Taxation: Evidence from Mauritius,” Annals of Tourism Research 32 (2): 478-498.

Kakazu, Hiroshi. 1994. Sustainable Development of Small Island Economies. Boulder, CO: Westview Press.

McKee, David L. and Clem Tisdell. 1990. Developmental Issues in Small Island Economies. New York, NY: Praeger Publishers.

Nichols, Mark W. and Mehmet S. Tosun. 2008. "The Income Elasticity of Gross Casino Revenues: Short-Run and Long-Run Estimates,” National Tax Journal 61: 635-652.

Newey, Whitney and West, Kenneth. 1987. “ A Simple Positive Semi-Definite, Heteroskedastic and Autocorrelation Consistent Covariance Matrix.” Econometrica 55 No. 3 (May): 703-08.

Purfield, Catriona. 2005. "Managing Revenue Volatility in a Small Island Economy: The Case of Kiribati,” IMF Working Paper WP/05/154.

Read, Robert. 2004. "The Implications of Increasing Globalization and Regionalism for the Economic Growth of Small Island States,” World Development 32 (2): 365-378.

Reece, William S. 2010. The Economics of Tourism. Upper Saddle River, NJ: Prentice Hall.

Sathiendrakumar, Rajasundram and Clem Tisdell. 1989. "Tourism and the Economic Development of the Maldives,” Annals of Tourism Research 16: 254-269. 
Sobel, Russell S. and Randall G. Holcombe. 1996. "Measuring the Growth and Variability of Tax Bases Over the Business Cycle.” National Tax Journal 49 No. 4 (December): 535-52. 
Figure 1. Sectoral Composition of GDP in 2008

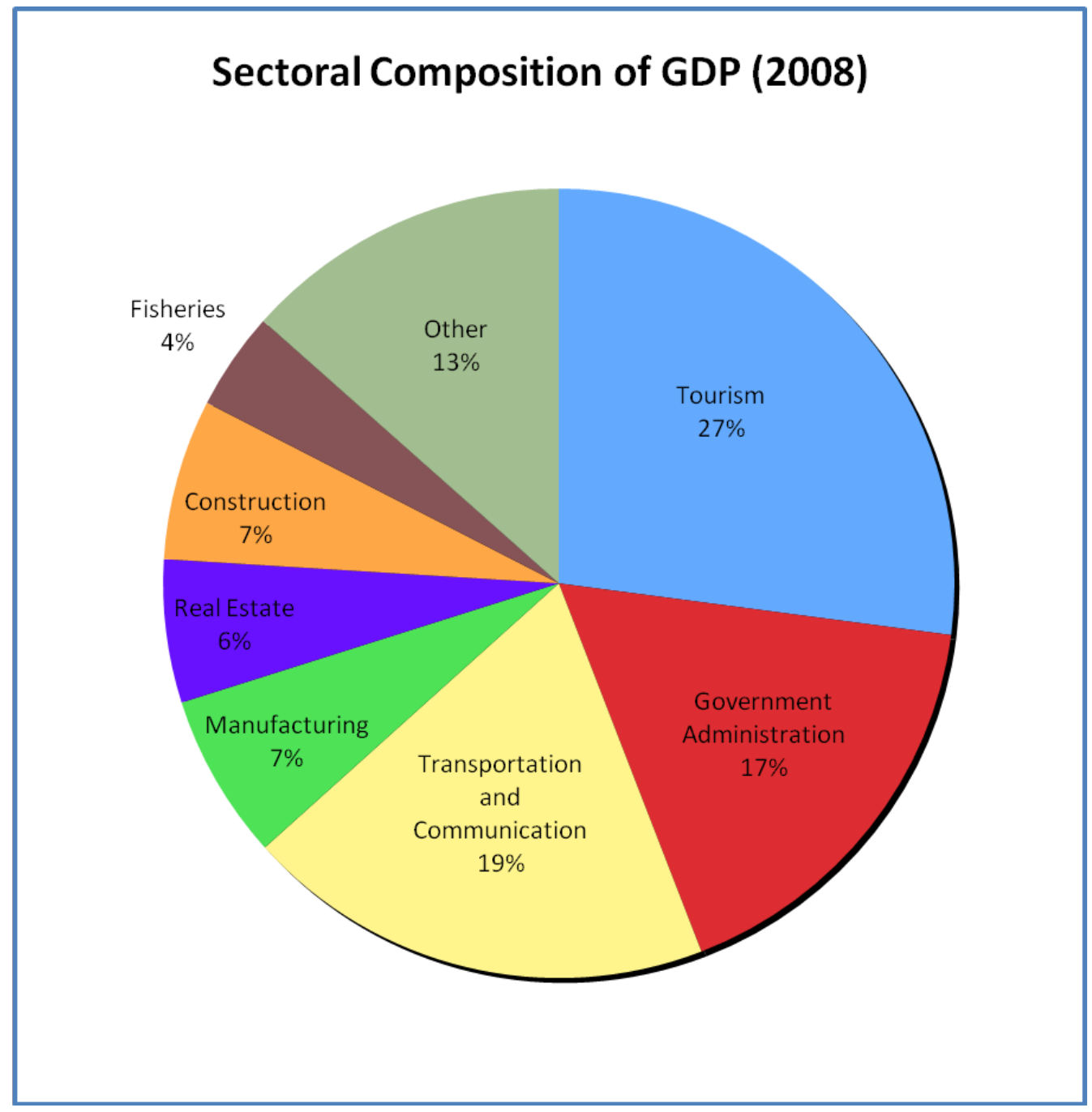

Source: Maldives Monetary Authority, Monthly Statistics November 2010. 
Figure 2. Total Tourist Arrivals (thousands of arrivals)

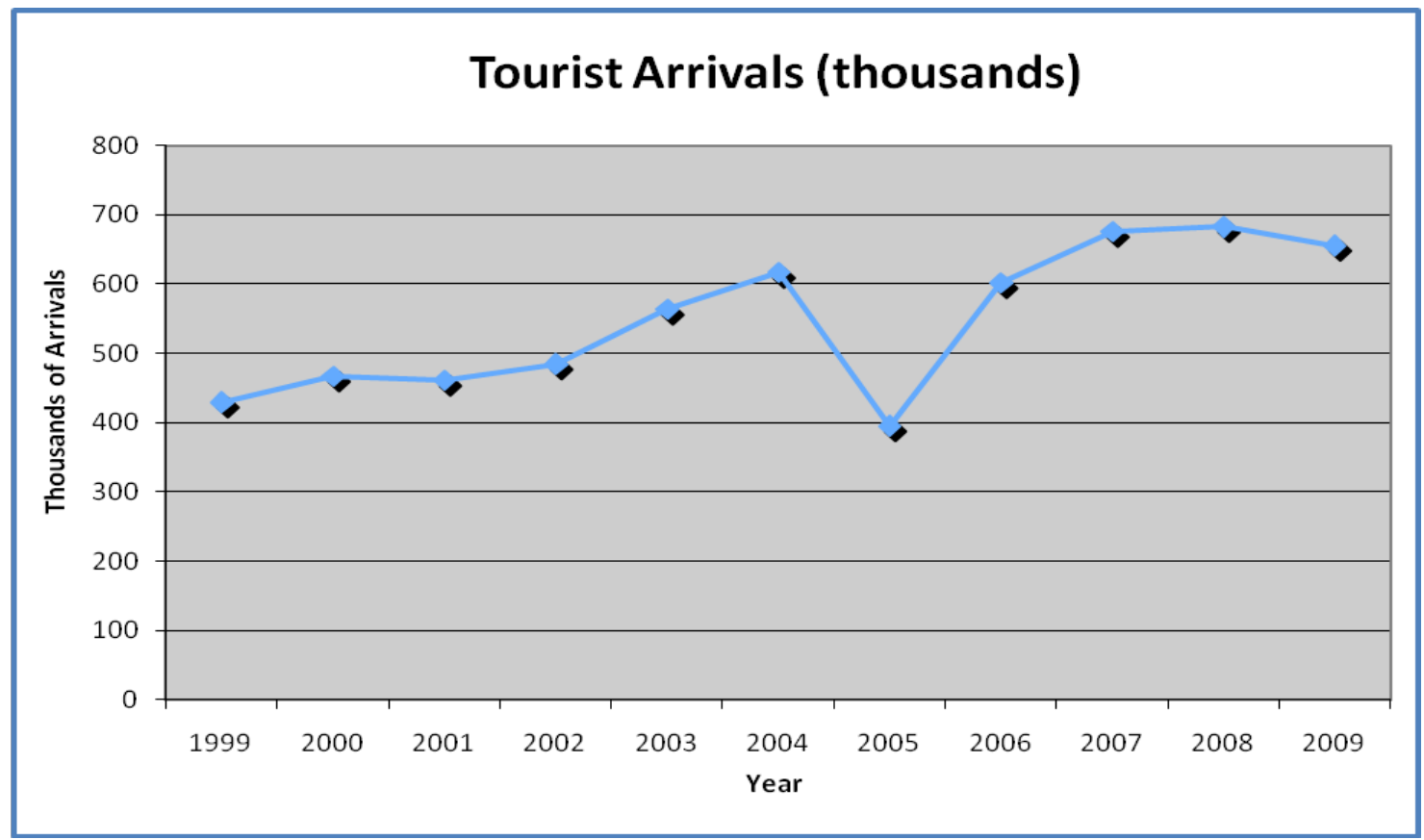

Source: Maldives Monetary Authority, Monthly Statistics November 2010. 
Table 1. Annual Tourism Indicators in Maldives

\begin{tabular}{|c|c|c|c|c|c|c|c|c|c|c|}
\hline & 2000 & 2001 & 2002 & 2003 & 2004 & 2005 & 2006 & 2007 & 2008 & 2009 \\
\hline Tourist Arrivals (thousands) & 467.2 & 461 & 484.7 & 563.6 & 616.7 & 395.3 & 601.9 & 675.9 & 683 & 655.9 \\
\hline Tourist Bednights (thousands) & 3,937 & 3,933 & 4,067 & 4,705 & 5,111 & 3,300 & 4,822 & 5,293 & 5,447 & 5,152 \\
\hline Tourist Bednights ( $\%$ change) & 5.9 & -0.1 & 3.4 & 15.7 & 8.6 & -35.4 & 46.1 & 9.8 & 2.9 & -5.4 \\
\hline Bed Capacity (resorts/ hotels) & 15,812 & 16,478 & 16,131 & 16,692 & 16,621 & 13,946 & 16,175 & 17,511 & 19,081 & 20,098 \\
\hline Bednight Capacity (thousands) & 5,788 & 6,015 & 5,887 & 6,092 & 6,083 & 5,093 & 5,904 & 6,392 & 6,964 & 7,337 \\
\hline Capacity Utilization Rate (\%) & 68.2 & 65.6 & 69 & 77.2 & 83.9 & 64.5 & 81.7 & 82.9 & 78.3 & 70.4 \\
\hline Average Stay (days) & 8.4 & 8.6 & 8.4 & 8.4 & 8.3 & 8.3 & 8 & 7.9 & 8 & 7.9 \\
\hline
\end{tabular}


Table 2: Summary Statistics for the Variables Used in the RegressionAnalysis

\begin{tabular}{lcc}
\hline & Mean & $\begin{array}{c}\text { Standard } \\
\text { Deviation }\end{array}$ \\
\hline International Tourist Arrivals & 485,429 & 123,213 \\
International Tourism Receipts (constant 2000 US\$) & $\$ 3.57 \mathrm{e}+08$ & $\$ 9.28 \mathrm{e}+07$ \\
GDP of Maldives (constant 2000 US\$) & $\$ 7.21 \mathrm{e}+08$ & $\$ 2.04 \mathrm{e}+08$ \\
GDP of European Union Countries (constant 2000 US\$) & $\$ 8.72 \mathrm{e}+12$ & $8.49 \mathrm{e}+11$ \\
GDP of OECD Countries (constant 2000 US\$) & $\$ 2.69 \mathrm{e}+13$ & $\$ 8.49 \mathrm{e}+11$ \\
GDP of High Income Countries (constant 2000 US\$) & $\$ 2.72 \mathrm{e}+13$ & $\$ 2.84 \mathrm{e}+12$ \\
GDP of North American Countries (constant 2000 US\$) & $1.09 \mathrm{e}+13$ & $\$ 1.33 \mathrm{e}+12$ \\
\hline
\end{tabular}

Source: Computed by the authors. 
Table 3. Estimated Long Run Tourism Tax Base Elasticities and Coefficients of Variation

\begin{tabular}{|c|c|c|}
\hline Relative to: & $\begin{array}{l}\text { International } \\
\text { Tourism } \\
\text { Receipts in } \\
\text { constant } \\
2000 \text { US\$ } \\
\text { (long run } \\
\text { elasticity) }\end{array}$ & $\begin{array}{l}\text { International } \\
\text { Tourist } \\
\text { Arrivals } \\
\text { (long run } \\
\text { elasticity) }\end{array}$ \\
\hline $\begin{array}{l}\text { GDP of Maldives in constant } \\
2000 \text { US\$ }\end{array}$ & 0.82 & 0.77 \\
\hline $\begin{array}{l}\text { GDP of European Union } \\
\text { countries in constant } 2000 \text { US\$ }\end{array}$ & 2.33 & 2.16 \\
\hline $\begin{array}{l}\text { GDP of OECD countries in } \\
\text { constant } 2000 \text { US\$ }\end{array}$ & 2.2 & 2.03 \\
\hline $\begin{array}{l}\text { GDP of High Income countries } \\
\text { in constant } 2000 \text { US\$ }\end{array}$ & 2.17 & 2 \\
\hline $\begin{array}{l}\text { GDP of North American countries } \\
\text { in constant } 2000 \text { US\$ }\end{array}$ & 1.78 & 1.66 \\
\hline
\end{tabular}

